\title{
The American West
}





\title{
The American
}

\section{A N E W I N T E R P R E T I V E H I S T O R Y \\ Robert V. Hine \& John Mack Faragher}

\author{
Y A L E U N I V E R S I T Y P R E S S New Haven \& London
}


Published with assistance from the foundation established in memory of Philip Hamilton McMillan of the Class of 1894, Yale College.

Copyright $\odot 2000$ by Yale University.

All rights reserved.

This book may not be reproduced, in whole or in part, including illustrations, in any form (beyond that copying permitted by Sections 107 and 108 of the U.S. Copyright Law and except by reviewers for the public press), without written permission from the publishers.

Set in Minion and Egiziano types by The Composing Room of Michigan, Inc. Printed in the United States of America.
Library of Congress

Cataloging-in-Publication Data

Hine, Robert V., 1921-

The American West : a new interpretive history / RobertV.Hine \& John Mack Faragher. p. $\mathrm{cm}$.

Includes bibliographical references and index. ISBN 0-300-07833-1 (cloth : alk. paper). ISBN 0-300-07835-8 (pbk. : alk. paper)

1. West (U.S.) - History. 2. Frontier and pioneer life-West (U.S.) I. Faragher, John Mack, 1945- . II. Title.

F591.H662 2000

$978-\mathrm{dc} 21$ 99-43653

CIP

A catalogue record for this book is available from the British Library.

The paper in this book meets the guidelines for permanence and durability of the Committee on Production Guidelines for Book Longevity of the Council on Library Resources.

$\begin{array}{llllllllll}10 & 9 & 8 & 7 & 6 & 5 & 4 & 3 & 2 & 1\end{array}$ 
FOR SHIRLEY

"Under the wide and starry sky... "

- RLS 
